\title{
Covid-19 Pandemisinde Mikrobiyoloji Laboratuvar Tanı Metodları
}

\section{Microbiology Laboratory Diagnostic Methods in Covid-19 Pandemic}

\section{Canan Eren}

Marmara Üniversitesi, Pendik Eğitim Araştırma Hastanesi, Tibbi Mikrobiyoloji ve Kan merkezi Departmanı, Pendik/İstanbul

\author{
Yazışma Adresi / Correspondence: \\ Canan Eren \\ Marmara Üniversitesi, Pendik Eğitim Araştırma Hastanesi, Tibbi Mikrobiyoloji ve Kan merkezi Departmanı, Pendik/İstanbul \\ T: +902166570606 E-mail: cananeren21@gmail.com \\ Geliş Tarihi / Received : 17.09.2020 Kabul Tarihi / Accepted : 07.10.2020 \\ Orcid: \\ Canan Eren: https://orcid.org/0000-0003-4726-8840 \\ (Sakarya Tip Dergisi / Sakarya Med J 2020, 10(4):700-704) DOI: 10.31832/smj.796411
}

$\ddot{O} z$

Endemi düzeyinde kalan SARS-CoV (Severe Acute Respiratory syndrome- Coronavirus) ve MERS-CoV (Middle East respiratory syndrome- Coronavirus)'i takiben, SARSCoV-2 (Severe Acute Respiratory syndrome- Coronavirus-2), 2020 başında, Çin Halk Cumhuriyeti'nin Wuhan eyaletinden yayllarak pandemiye sebep olmuştur. Diğer insan koronavirüslerinden klinik ve laboratuvar farklılıklar gösteren SARS-CoV-2'de tanısal işlemlerin optimum zamanlaması, tanı yöntemleri konularında araştırmalar devam etmektedir. Hastalığın tanısında ve takibinde PCR ve serolojik testler kullanılmaktadır. Bu derlemede COVID-19 (Coronavirus disease-19) pandemisinde mikrobiyoloji laboratuvar tanı yöntemleri güncel literatür ile özetlendi.

Anahtar SARS-CoV-2; RT-PCR; Seroloji

Kelimeler

Abstract

Following SARS-CoV and MERS, which remained at the endemic level, SARS-CoV-2 spread from Wuhan province of the People's Republic of China in early 2020, causing the pandemic. Researches continue on the optimum timing of diagnostic procedures and diagnostic methods in SARS-CoV-2, which shows clinical and laboratory differences from other human coronaviruses. PCR (polymerase chain reaction) and serological tests are used in the diagnosis and follow-up of the disease. In this review, microbiology laboratory diagnosis methods in the COVID-19 pandemic were summarized with the current literature.

Keywords SARS-CoV-2; RT-PCR; Serology 


\section{GIIRIŞ}

Coronovirus'lar Nidovirales takımında, Coronaviridae ailesinin Coronavirinae alt ailesine aittirler. Coronavirinae alt ailesi sekans özellikleri ve filogenetik ilişkilerine göre Alfa, Beta, Gama ve Delta coronavirus'lar olarak 4 cinse ayrılarak incelenir. Bu tiplerden sadece Alfa ve Betakoronavirüsler insanda hastalık oluşturabilir ancak hayvanlarda dört alt tip de görülür. SARS-CoV-2 (Severe Acute Respiratory syndrome- Coronavirus-2) pandemisine kadar insanlarda HcoV (Human Coronavirus)-229E, HCoVOC43, HCoV-NL63, HCoV-HKU1, SARS-CoV ve MERS$\mathrm{CoV}$ (Middle East Respiratory Syndrome-Coronavirus) enfeksiyon etkeni olarak tanımlanmıştır. ${ }^{1}$ İnsanda ağır alt solunum yolu enfeksiyonlarina sebep olan SARS-CoV ve MERS-CoV, yeni tanımlanan SARS-CoV-2 ile beraber Betakoronavirüs ailesine aittir. SARS-CoV 2002 yılında, ilk olarak Çin'de tanımlanmış ve kaynak olarak yarasa belirlenmiştir. ${ }^{1,2}$ SARS, 30'a yakın ülkede 8000'in üzerinde kişide enfeksiyona ve 700'ü aşkın kişide ölüme sebep olmuştur, virüse karşı aşı çalışmaları, epideminin tam kontrolü ve yeni vaka olmaması nedeni ile durdurulmuştur. $\mathrm{Bu}$ epidemiden 10 sene sonra MERS-CoV, deveden insana geçiş yaparak, bu güne kadar, çoğunluğu Suudi Arabistan'da olmak üzere 2000'i aşkın vakaya ve 800'ü aşkın ölüme yol açmıştır. ${ }^{3}$ SARS-CoV den farklı olarak, MERS-CoV enfeksiyonlarına halen rastlanmaktadır. ${ }^{4}$

SARS-CoV-2 ise Aralık 2019'da Çin'in Hubei Eyaleti, Wuhan Şehrinde ortaya çıkmış, kısa süre sonra virüsün genetik sekanslanması ile SARS-CoV ile taksonomik lişkili olduğu saptanmıştır. Asemptomatik enfeksiyon, uzun kuluçka süresi ve görece daha düşük mortalite ile seyreden SARS-CoV-2 enfeksiyonunun yaygınlaşması ile Mart 2020'de DSÖ (Dünya Sağlık Örgütü) tarafından pandemi ilan edilmiştir. ${ }^{3} \mathrm{Bu}$ derlemenin yazıldığı tarihte tüm dünyada yaklaşık 30 milyon kişide enfeksiyona rastlanmış, 1 milyon hasta da COVID-19 dolayısıyla kaybedilmiştir. Türkiye'de ilk vaka 10 Mart 2020'de kanıtlanmış, bu güne kadar 300000'e yakın vaka ve 7000 üzeri ölüm bildirilmiştir. $^{5}$

\section{SARS-CoV-2'nin yapısı}

SARS-CoV-2, 60-140 nm çapında, $30 \mathrm{~kb}$ uzunluğunda, tek sarmallı pozitif polariteli RNA içeren zarflı bir virüstür. Nükleotid dizisinin sekanslanması sonucunda SARS-CoV-2, SARS-CoV ile \%79, MERS-CoV ile \%51, Bat-SL-CoVZC45 ile \%87 benzerlik gösterdiği görülmüştür. ${ }^{1,6}$

SARS-CoV-2 RNA’sı, diğer pozitif iplikçik RNA virüsleri gibi enfekte ettiği hücrelerin sitoplazmasında viral proteinlerin üretilmesini sağlar. Patogenez açısından, yapısal proteinler olan, spike (S) glikoprotein, envelope (E) proteini, matriks $(\mathrm{M})$ proteini ve nükleokapsid $(\mathrm{N})$ proteini önemlidir. Ayrıca konakta bağışıklık sistemi ile etkileştiği düşünülen aksesuar proteinler de tanımlanmıştır. ${ }^{6}$

S proteini viral zarfta virüse adını veren çıkıntıları oluşturur, hücre membranında reseptör tanınmasını ve membran füzyonunu sağlar. Bu iki fonksiyon için sırasıyla S1 ve S2 subunitlerini kullanır. S proteini SARS-CoV ve SARSCoV-2 virüslerinde ortak olarak bulunan korunmuş bir bölüme sahiptir ve anjiyotensin dönüştürücü enzim 2'yi (ACE 2) reseptör olarak kullanmaktadır. ${ }^{6}$ ACE 2, alveolar yüzeylerde, solunum ve sindirim sistemi epitelinde, karaciğer safra kanallarında, böbrek parietal epitel hücreleri, santral sinir sistemi endotelyal hücrelerinde ve arter düz kas hücrelerinde bulunur. SARS-CoV-2' nin multisistem patogenezinin ardında ACE2 yaygınlığının ve diğer Betakoronavirüslere nazaran daha yüksek afiniteli S proteininin olduğu düşünülmektedir. ${ }^{7,8} \mathrm{~S}$ proteini, aşı ve ilaç geliştirilmesi açısından önemli bir hedeftir.

M proteini nükleokapsid-RNA kompleksinin oluşumu ve stabilizasyonunu sağlarken E proteininin virüs tomurcuklanmasında görev aldığ 1 düşünülmektedir. Viral partikül oluşumu ve salınımında M proteini ile birlikte rol oynayan $\mathrm{N}$ proteini ayrıca bir interferon anatagonisti olarak gözlenmiştir ve immün sistemin anti-viral yanıtının atenuasyonu ile ilişkili olabileceği düşünülmüştür. ${ }^{9}$ 


\section{Mikrobiyolojik tanı süreci}

\section{1- Örnek alınması ve saklanması}

Hastadan alınan örneğin türü, nereden ve hastalığın hangi evresinde alındığ ${ }_{1}$, teknik olarak örneklemenin doğru yapılması, örnegin laboratuvara ulaştırılma koşulları doğru tanı konmasında son derece etkin rol oynar. ${ }^{5}$ Sürüntü örnekleri tercihen rayon veya dakron uçlu çubuklarla alınmalıdır zira pamuk uçların nükleik asit amplifikasyonunda inhibisyona yol açabileceği öngörülmüştür. ${ }^{10}$ SARSCoV-2' de primer olarak solunum yolu örnekleri ile çalışıldı̆̆ 1 ve bu örneklerin toplanmasında neredeyse istisnasız olarak damlacık ve aerosol geliştiği için, örnek toplama, transport ve örneğin çalışılmasında görev alan personellerin kişisel koruyucu ekipmanı uygun şekilde kullanması şarttır. ${ }^{5,11}$

\section{1-a: Örnek türü}

Rutin klinik pratikte en sık rastlanılan örnek tipi nazofarinks ve orofarinks sürüntüsüdür. Genelde her iki alandan kombine preparat olarak gönderilir. Pnömonili hastalarda, özellikle negatif nazofarengeal sürüntü kültürünün ardından, klinik şüphe devamı durumunda balgam veya brokoalveolar lavaj (BAL) sıvısı da örneklenebilir. İnsanda pnömoni etkeni Betakoronavirüsler, solunum örnekleri dışında dışkı, idrar ve kanda da ispatlanabilir, ancak özellikle az semptom gösteren, viral yükü düşük hastalarda, bu alanlarda test güvenilirliği oldukça düşüktür (D1şkıdan \%29-40, idrardan \%7, kandan \%3-11). ${ }^{11}$

\section{1-b: Örnekleme için zamanlama ve önemi}

SARS-CoV-2'nin nazofarengeal/orofarengeal materyalle tanısı için en uygun zaman, semptomatik fazın ilk 5-7 gündür. Bir haftadan uzun süredir semptomatik hastalarda üst solunum yolu örneklerinin duyarlılığ azalmaktadır. $^{1,5}$

\section{1-c: Örnek transportu}

Örnekler alındıktan sonra hemen viral transport medyumuna ekilerek özel taşıma çantasında, +4 derecede muhafaza edilerek laboratuara ulaştırılmalıdır. Optimum olmamakla beraber, +4 derecede uygun korunmuş örnekler 48 saate kadar çalışılabilinir. ${ }^{1}$

\section{2- Laboratuarda tanısal yöntemler}

\section{2-a: Hücre Kültürü ve Sekanslama}

İnsanda alt solunum yolu enfeksiyonuna yol açan Coronavirus'lar (SARS-CoV, MERS-CoV ve SARS-CoV-2) Vero, LLC-MK2 gibi hücre hatlarında üretilebilmektedir ve terapötik ajan geliştirilmesi ve aşı çalışmalarında bu yöntem kullanılmaktadır. Ayrıca virüs genetik sekanslanması, filyasyon, yayılma yollarının ve zaman içinde virüsün mutasyon yükünün izlenmesi, virülans, bulaştırıcılık ve antijenisite takibi açısından önemlidir. ${ }^{12}$

\section{2-b: Moleküler Testler}

SARS-CoV-2' nin insanda tespiti için rutin klinik pratikte en sık olarak nükleik asit amplifikasyon testi türü olan RT-PCR (reverse transcriptase-polymerase chain reaction) kullanılmaktadır. Nazofarengeal, anal sürüntü, BAL ve üst solunum sistemi yıkamaları, uygun viral transport mediumları içerisinde PCR ile test edinilebilir. ${ }^{1,3,5}$ Rutinde kullanılan RT-PCR testleri nicel sonuç vermektedir ancak, pozitif sonuç viral yük konusunda bilgi vermez veya kültürde pasajlanabilinecek virüs varlığı için kanıt sayılamaz. Pozitif PCR testinin her zaman aktif hastalık veya bulaştırıcılık belirtmeyebileceği unutulmamalıdır. Aktif enfeksiyon sonrası viral fragmanlar pozitif teste yol açabilir. ${ }^{11}$ Benzer şekilde SARS-CoV-2 ile tekrar enfeksiyonun kesinlikle kanıtlanması için aynı hastada farklı iki mutasyona sahip SARS-CoV-2, PCR ile değil, genetik sekanslama yolu ile farklı mutasyonların gözlenmesi ile kanıtlanabilmiştir. ${ }^{13}$ RT-PCR, çeşitli kısıtlllıklara sahip olsa da COVID-19 enfeksiyonlarının doğrulanmasında ve taranmasında, standardizasyonunun ve lojistiğinin görece kolay olması nedeni ile rutin yöntem haline gelmiştir. RT-PCR için viral genomun değişik segmentleri hedeflenebilir. Çoğu zaman $\mathrm{S}$ (spike) ve $\mathrm{N}$ (nükleokapsid) genleri ve yapısal olmayan RdRp ve ORF 1a/b genleri, korunmuş, stabil bölgeler olmaları ve diğer viral genomlarla çok nadir çapraz reaksiyon göstermeleri nedeni ile hedef olarak seçilirler. ${ }^{11}$ Pandemi başlangıcında DSÖ yayımladığı rehberde, sadece 
SARS-CoV-2'nin genel dolaşımda olmadığı ülkelerde ilk olgunun tanısının doğrulanması için virus genomunda en az iki farklı bölgeyi hedefleyen nükleik asit amplifikasyon testini takiben virüsun genetik sekanslanmasını önermiştir. SARS-CoV-2'nin dolaşımda izlendiği bölgelerde tek hedef bölgeye yönelik RT-PCR yeterli görülmüştür, zira her durumda tetkik sonucu klinik ve radyolojik bulgularla korele edilmelidir. ${ }^{11}$

Ülkemizde SARS-CoV-2 için RdRp (RNA'ya bağıml RNA polimeraz) gen fragmanını hedefleyen tek adımlı ters transkripsiyon (RT) ve gerçek zamanlı PCR (qPCR) (RT-qPCR) uygulanmaktadır ve süreç T.C. Sağlık Bakanlığ 1 Halk Sağlığ 1 Genel Müdürlüğü Mikrobiyoloji Referans Laboratuvarı tarafından yapılan yetkilendirmelerle yönetilmektedir. Ülkemizde rutin kullanımda olan bu RdRp gen hedefli kit sadece SARS-CoV-2 ile pozitif sonuçlanmaktadir. Kit, 5-6 kopya SARS-CoV-2 / reaksiyon saptama sınırına sahiptir, analitik sensitivite $\% 99.4$ ve spesifite ise \%99.0 olarak bildirilmiştir. ${ }^{11,14}$

Analitik sensitivite ve spesifitesi yüksek olan SARS-CoV-2 RT-PCR testi, hastalığın doğasına, klinik evresine, örneğin yeri ve zamanına, örnek toplama tekniği ve transport şekline bağlı olarak daha düşük klinik sensitivite ve spesifite gösterebilmektedir. Bu durumda pozitif test daha güvenilir kabul edilmektedir. Kalitatif ve kantitatif NAAT (Nükleik asit ampflikasyon testi) ile klinik tablonun/prognozun korele olup olmadığı araştırılmaktadır.

\section{2-c: Seroloji}

Rutin klinik pratikte Covid-19 tanısında SARS-CoV-2 RNA'sı moleküler tanı yöntemleri ile saptanır. Ancak, moleküler testler, yatak başı veya bakı noktasında (Point of care) kullanımda kolaylık sağlamazlar, lojistik ve personel desteği gerektirirler. Dolayısıyla hastanın/etkene maruz kalanın SARS-CoV-2'ye karşı antikor yanıtının izlenebilmesi için serolojik (antijen ve antikor bağımlı) tetkiklere ihtiyaç vardır. Tipik olarak hızlı ve güvenilir seroloji kitleri, kullanım ve üretim kolaylığı ile test ulaşılabilirliğini ve yaygınlığını arttırırlar., ${ }^{1,5,11,13}$

Serolojik test geliştirilmesinde, SARS-CoV-2' de de SARSCoV ile benzer şekilde teknik zorluklarla karşılaşılmıştır. IFA, ELISA ve Western Blot yöntemleri yüksek sensitiviteye sahip olsalar da, diğer $\mathrm{CoV}$ antikorları ile çapraz reaksiyon nedeni ile düşük spesifite göstermişlerdir. Standardizasyon ve güvenilirliğin sağlanması için rekombinant antijenlerin geliştirilmesi gerekmiştir. ${ }^{15}$ SARS CoV N proteini alfa Coronavirus'lar ile \%25-29, beta Coronovirus'lar ile \%33- 47 benzerdir. S proteininde ise sirasiyla \%23-25 ve \%29 benzerlik görülmüştür. SARS CoV-2 için ise monoklonal antikorlar henüz hazırlık aşamasındadır. Ayrıca antikor yanıtı, konakçıya bağlı olduğu için, immün yanıt oluşmasının zamanlama ve klinik tablo ile korelasyonu, optimum viral / titrelerin olduğu dönemlerin örnek alınması açısından belirlenmesi oldukça önemlidir. ${ }^{15}$

Serolojik testler ile SARS CoV-2 ye karşı geliştirilmiş IgM, IgA, IgG gösterilebilinir. Hastaların çoğunda antikor cevabının virüs maruziyetinin 7-11. günlerinde geliştiği gösterilmekle birlikte bu süre değişebilmektedir. Dolayısıyla akut enfeksiyon tanısında antikor testleri an itibari ile faydalı değildir. ${ }^{15,16}$ Ayrıca antikor yanıtının stabil ve koruyucu bir immünite sağlayıp sağlamadığı tartışmalıdır. An itibariyle antikor testleri primer olarak temaslı izlenmesi (RNA saptayan testlere göre kullanım kolaylı̆̆ı) ve bölgesel/ulusal sürveyans açısından pratik faydalı olarak değerlendirilmektedir.

\section{SONUÇ}

SARS-CoV-2'ye karşı hastada oluşan antikorların saptanması, sürveyans, bağışıklığın karakterizasyonu, ileride aşı çalışmalarında etkinliğin öngörülebilmesi açısından önemlidir ve daha güvenli serolojik testler için çalışmalar devam etmektedir. Hem moleküler hem serolojik testler için optimal örnekleme zamanı, örnek tipi, popülasyonda klinik tablo-bağışıklık seyri arasındaki ilişkinin aydınlatılması gerekmektedir. 
Sakarya Tip Dergisi 2020;10(4):700-704

EREN, Covid-19 Pandemisinde Mikrobiyoloji Laboratuvar Tanı Metodları

\section{Kaynaklar}

1. Cui J, Li F, Shi ZL. Origin and evolution of pathogenic coronaviruses. Nat Rev Microbiol 2019; 17(3):181-192. doi:10.1038/s41579-018-0118-9.

2. Lu G, Wang Q, Gao GF. Bat-to-human: spike features determining 'host jump' of coronaviruses SARS-CoV, MERS-CoV, and beyond. Trends Microbiol 2015; 23(8):468-478. doi:10.1016/j.tim.2015.06.003.

3. Aydoğan S, Dinç B. Tỉbbi Mikrobiyoloji Laboratuvarı Açısından Sars-Cov-2. Türkiye Çocuk Hastalikları Dergisi 2020; 14(supp):18-25

4. Mackay IM, Arden KE. MERS coronavirus: diagnostics, epidemiology and transmission. Virol J. 2015;12:222. doi:10.1186/s12985-015-0439-5.

5. Altındiş M, Toptan H. SARS CoV 2 Laboratuvar Tanısı. Journal of Biotechnology and Strategic Health Research 2020; 4:1 (özel sayl):76-84.

6. Wu A, Peng Y, Huang B, et al. Genome Composition and Divergence of the Novel Coronavirus (2019-nCoV) Originating in China. Cell Host Microbe 2020; 27(3):325-328. doi:10.1016/j.chom.2020.02.001.

7. Ziegler CGK, Allon SJ, Nyquist SK, et al. SARS-CoV-2 Receptor ACE2 Is an Interferon-Stimulated Gene in Human Airway Epithelial Cells and Is Detected in Specific Cell Subsets across Tissues. Cell 2020;181(5):1016-1035.e19. doi:10.1016/j.cell.2020.04.035.

8. Hikmet F, Méar L, Edvinsson Å, Micke P, Uhlén M, Lindskog C. The protein expression profile of ACE2 in human tissues. Mol Syst Biol 2020; 16(7):e9610. doi:10.15252/msb.20209610.

9. Yuen CK, Lam JY, Wong WM, et al. SARS-CoV-2 nsp13, nsp14, nsp15 and orf6 function as potent interferon antagonists. Emerg Microbes Infect 2020; 9(1):1418-1428. doi:10.1080 /22221751.2020.1780953.
10. Durmaz B. COVID-19 Enfeksiyonunda Mikrobiyolojik Tanı. YIU Saglik Bil Derg 2020; 1:12-17

11. Togay A, Yilmaz N. SARS-CoV-2'nin Laboratuvar Tanisl. Tepecik Egit. Arast. Hast. Dergisi 2020; 30(Ek sayl):70-5.

12. Colson P, Lagier JC, Baudoin JP, Bou Khalil J, La Scola B, Raoult D. Ultrarapid diagnosis, microscope imaging, genome sequencing, and culture isolation of SARS-CoV-2. Eur J Clin Microbiol Infect Dis 2020; 39(8):1601-1603. doi:10.1007/s10096-020-03869-w.

13. To KK, Hung IF, Ip JD, et al. COVID-19 re-infection by a phylogenetically distinct SARS-coronavirus-2 strain confirmed by whole genome sequencing [published online ahead of print, 2020 Aug 25]. Clin Infect Dis 2020; ciaa1275. doi:10.1093/cid/ciaa1275.

14. Gurbuz M. Molecular and serological tests for COVID-19. Eurasian Journal of Pulmonology 2020; 22:4-9.

15. Lou B, Li TD, Zheng SF, et al. Serology characteristics of SARS-CoV-2 infection after exposure and post-symptom onset. Eur Respir J 2020; 56(2):2000763. doi:10.1183/13993003.007632020.

16. Farnsworth CW, Anderson NW. SARS-CoV-2 Serology: Much Hype, Little Data. Clin Chem 2020; 66(7):875-877. doi:10.1093/clinchem/hvaa107. 